\title{
Political risk, incentives and international credit market equilibrium***
}

\section{Carlos Hamilton Vasconcelos Araújo***}

\begin{abstract}
The present article discusses some important issues, dealt with in the literature, which are concerned with the problems faced by emerging economies in the international credit market. Initially, the incentives that encourage international investors to lend are investigated, with special emphasis on the portfolio diversification theory. Next, the incentives that encourage the emerging economies to borrow, and also those that lead to debt servicing, are addressed, with special emphasis on the theory of reputational equilibrium.
\end{abstract}

\section{Resumo}

Este artigo provê uma introdução sobre algumas importantes questōes exploradas pela literatura que trata dos problemas enfrentados por economias emergentes no mercado de crédito internacional. Inicialmente são investigados os incentivos que movem os investidores internacionais a emprestar, com destaque para a teoria da diversificação de carteira. No estágio seguinte, são considerados não só os incentivos que movem as economias emergentes a tomar emprestado, mas, principalmente, os que as levam a resgatar suas dívidas, onde ênfase especial é dada à teoria do equilíbrio reputacional.

Key Words: Political Risk, Capital Flows, Reputational Equilibrium .

JEL Code: F34, F21.

* To a great extent, the text replicates Chapter 1 in Araújo (2000).

** The author thanks the helpful comments made by professor Cristina Terra and by an anonymous referee, and also absolves them from the responsibility for any mistakes that might still exist. He'd also like to thank Luiz Malan for a final revision of the text.

${ }^{* * *}$ Department of Studies and Research, Banco Central do Brasil.

$\overline{\text { Brazilian Review of Econometrics Rio de Janeiro v.22, } \mathrm{n} \text {-2,pp.299-328 Nov.2002 }}$ 
Political risk, incentives and international credit market equilibrium

\section{Introduction.}

The globalization process of economic systems has the impressive growth of international capital flow as its hallmark. Drazen (2000) cites values attributed to the Bank for International Settlement, according to which, in early 1998, the daily turnover of traditional exchange rate instruments reached US\$1.5 trillion. At the same time and perhaps proportionally, the economic literature has shown great concern over this issue. If decades ago the focus of research was on the movement of the so-called productive capital, today the attention is riveted on financial capital flows. Following the classical tradition, the literature usually deals with direct investments in the light of the rate of return on physical capital (factor of production). With regard to indirect investments, the analyses are based on the monetary premium theory (interest rate parity). Given this fact, there would be an implicit differentiation between the economic functions of the two capital flows.

On the other hand, recent literature questions the differentiation of capital flows [see, for example, Claessens et alii (1995) and Araújo (2000, Chapter 3)]. Within this context, the different capital flows are intuitively viewed only as financing alternatives to a deficit in the current account balance of payments - in globalized markets, no-arbitrage would be observed. By the way, the concept introduced by Aliber (1973) and the interpretation made by Dooley and Isard (1980) of political risk (sovereign risk) are comfortably inserted into the proposal concerning the non-differentiation of capital flows. The definition provided by Aliber (1973) takes into consideration the uncertainties produced by the possibility of the public power intervening in credit contracts and regards political risk as the probability that the State authority has of intervening between the investors of a country and the investment opportunities in another country. Dooley and Isard (1980), however, interpret political 
risk as the probability of control over capital flows in a given country.

In this sense, the present article does not distinguish capital flows between direct and indirect investments, addressed to public and private agents, etc. Consequently, treating any external liability component of an economy as sovereign debt is extremely far-fetched. However, this option is justified by the fact that, regardless of whom the debtor or creditor is, or independently of the type of liability of the importer's country, these obligations are liable to the same political risk, since all debtors come under the jurisdiction of the same State ${ }^{1}$.

This article does not intend to exhaustively explore the literature on this issue, but instead, it attempts to assess the state of the art regarding the incentives that encourage international capitalists to lend, to those who ex ante lead the emerging economies to borrow and to those who ex post lead these economies to service their debts. This issue is of paramount importance since there is no regulation for international capital flows and, consequently, from the juridical standpoint, the penalties applicable to debt defaulters are lenient. In short, the article presents a panorama of the literature on the survival of international credit market in this "hostile" environment.

Aside from the introduction, there are another three sections. The next section focuses on the behavior of international creditors, especially with regard to the theory of risk diversification. Section 2 deals with the behavior of debtors, with emphasis on reputational equilibrium. The final section presents the conclusions.

\footnotetext{
${ }^{\mathfrak{l}}$ For further details on the several types of risk involved in credit operations in the international market, see for example Buiter (1983).
} 
Political risk, incentives and international credit market equilibrium

\section{Incentives that encourage creditors to lend.}

According to the terms expressed by the classical theory about the movement of factors, the expected rate of return is the only determinant of international capital flow*. The expectation of a higher return would encourage international credit market suppliers. Macroeconomically speaking, capital flows would lead to a higher Pareto state of nature as they would increase the national income of the exporting economy. The classical theory could therefore satisfactorily explain the dislocation of the capital factor from relatively rich regions, with a high savings stock and low marginal productivity of capital, into poorer regions, with a low savings stock and high marginal productivity of capital.

The classical theory is well summarized in Fisher's notion of interest rate parity which, under the hypothesis of no financial repression, presupposes the nonexistence of excess profit in any market of the capital factor. After the compensation of exchange devaluation, the rates of return would be the same in different economies. On the other hand, following the interpretation of Eaton and Gersovitz (1983) and of Edwards (1984,1986), in which " $\pi$ " and " $s$ " are respectively the probability for a country to default and the spread charged from the same country on the international reference interest rate, $s=\varphi \pi$ (with $\varphi$ constant). Therefore, on principle, under the restricted view of the theory of interest rate parity, the survival of the international credit market would be jeopardized in the presence of political risk. In addition, the classical theory does not provide enough justification for the phenomenon of simultaneous investments between rich countries. Heavy remittance of money from the United States to Western Europe and vice-versa is observed. In these two regions, roughly speaking, political risk is nonexistent and the rates

*See for example, Lucas (1990). 
of capital return are equivalent.

The gap left by the classical theory is initially bridged by the theory of portfolio diversification formulated by Markowitz in the 1950's. The mean-variance model represented a major advance by admitting that the individuals seek less uncertainty in their investment decisions, in addition to a greater expected return. Given this aspect, in Markowitz's world the composition of the individual portfolio consists of the optimal combination between expected return and risk, the only two arguments of the agents' utility function ${ }^{3}$.

The combination of the ideas expressed in the theory of risk diversification and in the theory of interest rate parity, even in the presence of political risk, allows validating the parity conditions and rationalizing the permanence of suppliers in the international credit market. If there is no sovereign risk when the remittance of resources to another country reduces any other risks to which a risk-adverse investor is exposed, even with a slight loss in the expected return, this investor has incentives to insist on the operation. If there is sovereign risk, although the expected return remains constant, the investor persists with the remittance of resources, provided that the welfare losses due to political risk exposure do not equal the gains obtained from the reduction of other risks. An intermediate point supposes welfare losses due to political risk exposure and due to the reduction in the expected return, offset by the gains obtained from the diversification of other risks.

Although the consolidation of theoretical support dates back to the 1950's, the formal investigation of welfare gains by means of risk diversification on an international basis was initially established by Grubel (1968). Based on the structure of the portfolio selec-

\footnotetext{
${ }^{3}$ The agent's utility function is supposed to be strictly concave in its two arguments. In its turn, the expected utility function is of the von Newmann and Morgenstern type. For more information see, for example, Simonsen (1983).
} 
Political risk, incentives and international credit market equilibrium

tion model, the investigation is conducted in a world formed by two countries, in which: (i) full employment exists; (ii) wealth is accumulated by means of the purchase of physical capital, currency or public bonuses; and (iii) initially autarkic, the now open economies exchange consumer goods and/or bonuses, but they do not exchange physical or monetary capital goods ${ }^{4}$.

Within Grubel's context (1968), the combination between external and internal bonuses in the portfolio depends on the agents' preferences in terms of risk and return, and also in terms of current and future consumption. Three results are relevant: (i) international flows are responses to the interest rate differential and to the accumulation of assets in both economies; (ii) when the agents' preferences, the bonus returns, the return variances and the wealth of both countries are the same, the aggregated demands of each country for bonuses issued by the other country are the same; and (iii) when the difference between countries lies only in interest rates, the capital can flow between them in both directions, wherein the trade-off between expected return and diversification is very clear ${ }^{5}$.

The rationalization of the survival of the credit market could follow a different path and, in Cartesian terms, be carried out in two stages. Firstly, one questions whether diversification implies welfare gains, which is positively answered if we take the hypotheses of the mean-variance model. Secondly, it is necessary to discuss how to proceed in order to obtain optimal gain or, by putting it differently, which wealth proportion the investor should allocate to each country. On principle, the mean-variance model also answers

\footnotetext{
${ }^{4}$ This conjecture implies that openness does not affect return and variance of both physical and monetary capital, which centers the discussion on changes in bonus position.

${ }^{5}$ Grubel (1968) carries out an empirical assessment of his theory based on the ex post return of the stock market in eleven industrialized countries and, in general, concludes that diversification produces relevant welfare gains to the North-American investor.
} 
the last question, however, given the rigidity of the presuppositions under which the answer is obtained ${ }^{6}$; in general, economists turn to another construction of the finance theory: the Capital Asset Pricing Model - CAPM ${ }^{7}$.

The CAPMI considers, among other improvements, the condition of equilibrium of the risky asset market and the existence of a market portfolio. As to diversification, the CAPM postulates that when the assets are randomly selected and equally distributed in a portfolio, the associated risk is minimized as the number of included assets increases $^{8}$. Applied to the field of international finances, this assertion strengthens the idea that international capital flow reduces portfolio risk as the assets of different economies are attached. Therefore, it is necessary that the perfect correlation between the return of those assets issued by the capital exporting economy and the return of the assets issued by importing capital economies not exist. Nevertheless, in both situations, that is, in the case of the amount of assets included in the portfolio and the correlation between its return, the process would have some restrictions because: (i) the number of autonomous economies is low; and (ii) even if the number of autonomous economies were large, when the correlation is perfect, the nonsystematic risk (not associated with the global market portfolio) cannot be reduced.

One should know that even in economies whose opening pro-

\footnotetext{
${ }^{6}$ Two are the restrictions observed: (i) for arbitrary preferences, the model can only be motivated if we admit that the rates of return of risky assets have a normal distribution; and (ii) for arbitrary distributions of the rates of return of risky assets, the restriction is imposed on the utility function, which must be quadratic [see, for example, Huang and Litzemberger (1988, chapter 3)].

${ }^{7}$ See, for example, Huang and Litzemberger (1988, chapter 4).

${ }^{8}$ Evans and Archer (1968) conclude that the number of assets that diversify a stock market portfolio is approximately ten; Francis (1986) considers that diversification is superfluous and should be avoided for more than 10 or 15 assets; Statman (1990), however, advocates that no fewer than thirty stocks are necessary to have a well-diversified portfolio.
} 
Political risk, incentives and international credit market equilibrium

cesses are mature, the capital markets are autonomous in relation to external markets. In addition, there almost always exists an independent monetary zone and there is always a sovereign political and institutional organization. On the one hand, this kind of factors contribute towards maintaining a high level of correlation between the returns of assets issued by an economy; on the other hand, they contribute towards a low correlation between the returns of the assets issued by an economy and the returns of assets issued by another. Thus, we may infer that the investor diversifies by going from the autarky to international market and, if adverse to risk, he has welfare gains.

Levy and Sarnat (1970) use the static version of the CAPMI in order to study the stock market and investigate whether international diversification brings welfare gains to the North-American investor. When the sample is restricted to stocks issued in sixteen industrialized countries ${ }^{9}$, there is some evidence of marginal gains; however, when it includes stocks issued in twenty-eight countries, the evidence points to considerable gains. In the latter case, depending on the level of interest rates in the United States, the participation of stocks in portfolio composition,10 issued in developing countries, is relatively high, between $40 \%$ and $60 \%{ }^{10}$. This could be justified by the low covariance between the return of assets in developing countries and in the other twenty-three countries.

The static version of the CAPMI (similarly to the mean-variance model) is based on the premise that investors only look to the present, a myopia that is justifiable only when the group of investment options is stationary ${ }^{11}$. In general, however, stationarity does

\footnotetext{
${ }^{9}$ The text does not name any countries, but it is clear that Japan is not included.

${ }^{10}$ The countries considered in the sample were Venezuela, Mexico, South Africa, New Zeland and Japan.

${ }^{11}$ The same is valid when the investor's utility function is logarithmic, a case in which the
} 
not exist and the agents assess the future, for example, they acquire insurance contracts against changes in the set of investment options. This behavior is taken into consideration by the dynamic version of the CAPM, originally presented in Merton (1973). On the other hand, Solnik (1974) argues that, even in its dynamic version, the CAPMI cannot be extended to the international context by the simple inclusion of foreign assets in the market portfolio. In Solnik's (1974) assessment, the procedure does not represent a general equilibrium and, consequently, the model would lose all of its contents and economic appeal.

Aside from raising the issue, Solnik (1974) comes up with the following solution: an intertemporal equilibrium model for the international capital market, where the behavior of asset prices is consistent with the idea of one globally integrated market. The proposition made by Solnik (1974) contemplates the existence of exchange risk and of mechanisms that allow the investor to get insured against this type of risk. Among the results provided by the theory in question, one should especially mention the equality for two economies between the interest rate differential and the sum of the expected variation in exchange parity with a term that depends on the covariance between exchange risks in such economies ${ }^{12}$.

Grauer and Hakansson (1987) assess welfare gains associated with intertemporal diversification by means of a pure version of the multiperiod reinvestment model ${ }^{13}$. For that reason, they consider the existence of four types of assets - treasury bills, public bonuses, private bonuses, stocks - in the North-American market and in another

\footnotetext{
optimal investment policy is constant and allocates a fixed parcel of wealth to each asset.

${ }^{12}$ As Solnik (1974) puts it, this implies that the exchange rate in the futures market is a biased estimate for the future spot exchange rate.

${ }^{13}$ This is an alternative to dynamic CAPM. For further details, see Grauer and Hakansson (1986).
} 
fourteen assets - stocks or bonuses - of different nationalities. For the 1968?85 interval, with controlled risk aversion, portfolio selection and level of financial leverage, they observe that: (i) there are substantial gains with the insertion of non-North-American assets into the market, especially as a conservative strategy; and (ii) the gains when lifting the restriction of non-leverage are higher with the existence of non-North-American assets. Moreover, there is strong evidence of market segmentation, since the optimal level of investment practically ignores the risky North-American assets whenever the investor is allowed to acquire assets from other economies.

Merton (1984) splits the decision of investment into two parts: (i) selection between consumption and savings; and (ii) portfolio selection. Both decisions, however, can be interpreted the same way: they seek to smooth and increase consumption, although it is no easy task to identify which motivation is more relevant. From the classical theory viewpoint, the increase in consumption is more relevant, since this line of argument considers the rate of return as the only determinant for the international capital fow. On the other hand, some authors advocate that welfare gains obtained through diversification are essentially linked to consumption smoothing. According to Cole and Obstfeld (1991), the gains are the result of the international spread of domestic consumption risk; van Wincoop (1994), on the other hand, states that what worries the agents is the variability of consumption.

Instead of having the mean and variance of the return of assets as paradigms, a usual practice in researches international diversification, Cole and Obstfeld (1991) measure the expected utility based on the evolution of the product (consumption). This way, social gains with the exchange of assets between two industrialized economies result from the transfer, by means of terms of trade, of random 
shocks to product (consumption) ${ }^{14}$. The strategy is defensible because, ceteris paribus, the terms of trade of a country are negatively correlated with the growth of the export sector. Roughly speaking, the exchange of assets provides an insurance against unexpected variations in product (consumption) and, consequently, smoothes its trajectory.

In a pure exchange model adjusted for the economies of the United States and Japan, Cole and Obstfeld (1991) have found a slight welfare loss $(0.20 \%$ of the national product a year) when the economies move from a stage of perfect integration to an autarky since, in this case, the current account movements act as diversification substitutes ${ }^{15}$. The marginal character of gains obtained through economic openness indicates that even restrictions on the exchange of assets would discourage the capital flow between industrialized economies.

van Wincoop (1994) shows the restriction on two countries as a weak point of the surprising results obtained by Cole and Obstfeld (1991) and, on the other hand, assesses potential welfare gains based upon the data on the consumption of twenty OCDE countries $^{16}$. Even though van Wincoop (1994) recognizes that countries have some diversification via the stock market, direct investments abroad or via current account fluctuations financed by risk-free assets, he argues that there are great opportunities for risk diversification, since, for the average country in the considered sample, the

\footnotetext{
${ }^{14}$ The underlying reasoning offered is that, given the level of savings, if product variance in autarky is large, so will be the consumption variance.

${ }^{15}$ Golub (1990) dra ws a diametrally-opposed conclusion, based on the negative correlation between the profits of American and Japanese companies, which was also detected by Levy and Sarnat (1970).

${ }^{16}$ Australia, Austria, Belgium, Canada, Denmark, Finland, France, Gernnany, Greece, Iceland, Ireland, Italy, Japan, Holland, Norway, Spain, Sweden, Switzerland, England and United States
} 
Political risk, incentives and international credit market equilibrium

variance of the growth rate of traded goods consumption is twofold that of the aggregated demand. The assessment of gains shows that on average they could reach up to $5.60 \%$ of the product a year.

Grossman and Han (1997) go back to the path of consumption smoothing. They recognize that the literature often used sovereign debts as a mechanism of intertemporal consumption smoothing in the presence of a stochastic consumption sequence; they also argue that there would not be a consensual agreement on whether smoothing per se could support the existence of an amount of debt without collaterals. In general, the study conducted by Grossman and Han (1997) is not so different from that of Eaton and Gersovitz $(1981,1983)$, except for the fact that in the framework constructed by the former authors, smoothing by means of contingent debt issuance could not be sustained.

It is important to mention that the authors above show that indebtedness with the aim of smoothing consumption is conditioned on the nature of the penalty applied in case of repudiation, and also on the way through which smoothing is materialized -issues or debt service contingent on realizations of income.

\section{Incentives that encourage debtors to pay.}

Under the paradigms of the classical theory, a larger expected return is the stimulus to move the decisions of international credit market suppliers; in the view of macroeconomics, there would be an increase in the national income in the exporting economy. In the perspective of the importing economy, the agents would demand external capital because the marginal product would be superior to the marginal cost. In macroeconomic terms, the receipt of external funds would increase the national product, since they would finance investments that would generate more income than would be necessary to service the debt. 
The picture developed above initially points to the equilibrium of a game with positive sum, but in fact, the issue is more complex. Ex ante, the international investor chooses between applying his resources in domestic economy and applying them abroad. In its turn, the receiving country would have two alternatives as well: not to receive the foreign resources or to receive them with the ultimate aim of paying them later. By the previously raised arguments, at this point of the game, the second alternative would bring a better return for the importing country and would therefore be preferred. On the other hand, ex post (once the resources are received), perhaps a third alternative would be better: to promote expropriation ${ }^{17}$. There would be a time inconsistency problem (the equilibrium would not be perfect in subgames), as a result of the fragility of coercive methods against sovereign debt defaulters. Therefore, an unexplored issue arises in the classical theory: why sovereign debtors do not make an appropriation of the resources received. Inverting the coin, because even without legal protection international investors grant credit to sovereign economies. Apparently, there would be irrational behavior of both parts.

By referring to the "enigma" of the exposure of international investors to the risk of sovereign default, Chowdhry (1991) underscores that the only effective way of inducing debtors to payment is to use self-sustainable mechanisms. The partial and transient exclusion of defaulting countries from the international credit market has been the most widely used strategy. It is a powerful pressure mechanism because its use makes the debtor record losses in function of smoothing and increasing in consumption losses. One should therefore elucidate how the literature formalizes the mentioned self-sustainable

\footnotetext{
${ }^{17}$ In the text, the terms repudiation and expropriation are employed indistinctly, but without detriment to comprehension. In general, literature uses the former one to refer to default in case of financial capitals (indirect investments) and the latter for physical capitals (direct investments).
} 
mechanisms, how it provides the behaviors of the sovereign debtor and of the international creditors with economic rationality. In the present study, however, we will discuss only the reputational equilibrium, a theoretical framework according to which the sovereign debtor seeks to build the reputation of a good payer by carrying out the contracts. This way, they can have access to the international credit market.

\subsection{The defense of reputational equilibrium.}

In this subsection, the state of the art or theories that defend the reputational equilibrium are analyzed.

Eaton and Gersovitz (1983) pioneered a study on reputational equilibrium. According to the proposed modeling, the consumption and investment trajectories stem from the optimal selection of capital flows, made by a central planner in an environment where the only relevant market imperfection is the repudiation risk- sovereign risk. The establishment of hostile measures on international capital is contained by the negative effect they would exert on the expectation of potentially new investors. Thus, the central planner's selection derives from his strategic behavior in relation to creditors, and vice?versa, confronting benefits and losses associated with default the survival of the international credit market represents a perfect subgame equilibrium.

Albeit simple, the theory postulated by Eaton and Gersovitz (1983) leads to intuitively substantial conclusions: (i) disregarding the restriction that makes the indebtedness strategy of the representative agent intertemporally consistent, the optimal selection of the capital importer is to expropriate in the first period and not to expropriate in the subsequent periods; (ii) the probability that the debtor country will sustain the non-expropriation policy increases proportionally to the reduction of its intertemporal discount rate 
and of the international interest rate; and also proportionally to the increased difference between the capital stocks of the open economy and of the autarky.

The first assertion agrees with the previous assessment that in the presence of sovereign risk, investors do not have incentives to lend and debtors do not incentives to pay. Consequently, the international credit market does not survive. The second assertion suggests that the patience appreciation of future consumption - discourages expropriation of external capital since this would imply an increase in consumption only in the short run. From (ii), we infer that a country with low domestic capital stock is more likely to pay its debts, which can be ascribed to the high marginal product of this factor. Finally, (ii) shows that the lower the international interest rate, the higher the cost/benefit ratio of the default.

An apparently important issue was not addressed in the theory postulated by Eaton and Gersovitz (1983): in general, in countries where the capital stock is low, so will be the product. Therefore, the marginal utility of consumption is high, which is unfavorable to the decision to pay the debt. Under the circumstances mentioned above, there is a high consumption loss due to the lack of credit in the external market. This way, only when the first impact is weaker (substitution effect) than the second one (income effect), the low domestic capital stock removes the default.

Grossman and van Huyck (1988) suggest that the history of the international credit market allows for some generalizations: (i) default events are associated with bad states of nature and they are often partial; and (ii) the sovereign states usually qualify for new loans shortly after a default. In view of this, these authors develop a model that regards sovereign debt as a contingent asset ${ }^{18}$, which is useful for the transfer, albeit partial, of the losses from events that

\footnotetext{
${ }^{18}$ Eaton et al (1986), just like Grossman and Han (1997), also view sovereign debt as a contin-
} 
negatively alter the wealth of debtors to external creditors.

Under the hypothesis of common (and previous) knowledge of the distribution of the probability of bad state of nature, some defaults (e.g., partial service) are classified as excusable and do not exclude the debtor from the credit market. On the other hand, even in bad states of nature, the cases of repudiation are held as unacceptable. To simplify the formalization without compromising the quality of the analysis, Grossman and van Huyck (1988) suppose that: (i) sovereign debtors do not use their own savings or the external savings to finance the current consumption; and (ii) both debts and investments reach maturity in one period. Also considering the assumption that the shocks that affect wealth are stationary, they turn the intertemporal problem of the debtor into a static problem.

The theory by Grossman and van Huyck (1988) provides a sustainable reputational equilibrium, with the possible occurrence of justifiable defaults and without the repudiation ever being chosen, even with a significant level of attractiveness in good states of nature. In the equilibrium, the effective accumulation of capital by the debtor economy (a transfer of risk to creditors) is affected by restrictions, even if efficiently financed in the international market. This occurs because the amount of foreign debt that can be acquired is subject to limits, which narrow down as: (i) the intertemporal discount rate of the debtor increases; (ii) the possibility of credible to noncredible change in the ruler of the debtor economy; (iii) the probability that creditors will not forget previous repudiations also increases; (iv) risk aversion on the part of the debtor decreases; and (v) the rate of return of capital in domestic economy decreases.

Chowdhry (1991) also investigates how the fulfillment of credit contracts is attainable in the international market. By proposing

gent asset. 
the smoothing of the penalties imposed on debtors in case of default, this author, to some extent, follows Grossman and van Huyck (1988). Specifically, Chowdhry (1991) admits that countries lose the concession of credit only in financial institutions with which they have irregular debts. However, as the number of institutions is limited, if the default events are repeated, the debtor will inevitably be excluded from the international credit market.

The approach explores the stylized fact that bankers form unions and, with the need to build their reputation, they refuse new credit to debt defaulters. The behavior aims at showing strict measures, since passive attitudes indicate null costs to the other debtors in case of default. The multiplicity of debtors and the existence of a limited number of creditors are essential to the efficiency of the strategy adopted by the banks with the aim of creating a remedy that sufficiently deters repudiation. It is important to observe that the reduced number of creditors implies that the market is not competitive, differently from what other authors suppose. Chowdhry (1991) concludes that partial default does not occur and justifies this fact as being a reflex of penalty insensitivity - exclusion from the credit market - at the level of default.

In the seminal article written by Eaton and Gersovitz (1983) it is explicitly shown that there would be a lot of uncertainty left even if the international investor could gather and assimilate all the available information on investment opportunities beyond his country's frontiers. Comparatively to the lender, the borrower would typically have safer information on the perspective of servicing an occasional credit operation. Although the literature treats it as microeconomic distortion, information asymmetry would perfectly fit the concept of political risk, given as a macroeconomic distortion ${ }^{19}$.

\footnotetext{
${ }^{19}$ See, for example, Hermalin and Rose (1999).
} 
Political risk, incentives and international credit market equilibrium

The differentiation outlined above is only informative, since the literature, in general, does not distinguish between information asymmetry and political risk. Kletzer (1984), for instance, presents a theoretical model to analyze international loans in the presence of sovereign risk. For that reason, this author emphasizes the information asymmetry between debtors and creditors, as to the level where the debt service obligations of the capital importing country is at. In this environment, the lenders have to turn to threats of future credit denials and interruptions in the international trade in order to discourage repudiation.

As study object of the contract theory, information asymmetry is motivated by moral hazard and adverse selection. By the way, Atkenson (1991) examines the mechanisms that guarantee the payment of loans granted to sovereign countries subjected to moral hazard - the creditors do not know the debtor's actions regarding the destination (investment or consumption) given to loan resources. The investigation includes the hypothesis that the optimal payment of debts increases with the volume of investments, which allows Atkenson (1991) to come up with a remarkable result: the capital flow trajectory is such that the debtor exports capital in periods in which the level of his product is low.

In the terms of the theory proposed by Atkenson (1991), the conclusion presented above indicates that a low realization of the product means high probability that the debtor has not invested or has done so minimally. Intuitively, if excluded from the credit market in periods which high realizations of the product are observed, the country would have fewer losses. The optimal contract, therefore, should take this information into consideration and demand fewer payments in such situations; on the other hand, debt service should be relatively higher in moments of reduced production.

Undoubtedly, Atkenson (1991) reaches an instigating point: on 
the one hand, he agrees with the widespread idea that the capital should flow towards the debtor countries exactly at the moments of reduced production (consumption smoothing); on the other hand, he accepts the historical evidence that international creditors demand an elevated debt service at the very moment their debtors are faced with crises. By the way, Frankel (1995) corroborates the argument that countries tend to get burdened with debts internationally when they experience acceleration, and tend to pay while in deceleration. This behavior results from flaws in the theory of intertemporal optimization.

Cole et al (1995) also work on information asymmetry and construct their theory under the hypothesis that debt defaulters regain access to the international credit market after the partial service of irregular debts. Their approach resembles the proposal made by Grossman and Van Huyck (1988), who rely on the historical evidence that many countries default, but after some time, go back to the international credit market as debtor ${ }^{20}$. There is, however, a remarkable difference between the two articles: in the second one, the return of the debt defaulter to the credit market is only possible when the default is excusable; in the first one, this also occurs when there is a "Markov" switch of government ${ }^{21}$.

The strategy drawn up by Cole et al (1995) involves a problem of adverse selection - the type of government is not identified by the creditors. The government shows market participants the intention to fulfill the contracts by means of the regularization of defaults. Considering the possibility of a switch in government, the selection takes into account the probability of its maintenance in power and

\footnotetext{
${ }^{20}$ Note that, up to the moment, the necessity of excluding a defaulting country from the international credit market in operations in which it participates as creditor has not been established

${ }^{21}$ An unstable government that has declared or declares default is replaced with a stable government, which does not employ such resource.
} 
Political risk, incentives and international credit market equilibrium

defines a perfect "Bayesian" equilibrium where an unstable government always declares default while a stable government does not. Note that after a default and a subsequent change in government, the new government promotes the regularization of debt as a sign to market participants that it has a stable profile.

In Fafchamps' view (1996), renegotiation processes, characteristic of sovereign debts, generate problems with payment incentives. Furthermore, "conditionalities" 22 would be an effort, although partial, of the debtor's commitment to the service of his debts. Based on this, Fafchamps (1996) develops a model with the aim of assessing the influence of structural adjustments and of conditionalities over the behavior of sovereign debt defaulters. Fafchamps obtains a perfect equilibrium in subgames, and concludes that conditionalities encourage debtors to service larger debt stock installments in process of renegotiation. This may occur due to the adoption of a strategy by the creditor, in which the debtor keeps part of the efficiency gains produced by the expansion of the external market as a result of the structural reform imposed on the economy ${ }^{23}$.

The theories discussed so far, either implicitly or explicitly, suppose that a defaulting country cannot obtain new loans. For instance, in the model developed by Eaton and Gersovitz (1983) and in the model proposed by Atkenson (1991), the exclusion from the credit market is definitive; whereas in the model by Grossman and Van Huyck (1988) and in that proposed by Cole et al (1995), the exclu-

\footnotetext{
${ }^{22}$ Circumstances under which sovereign debts are renegotiated. Especially if carried out with the intervention of multilateral institutions- International Monetary Fund, World Bank or International Rediscount Bank - in general, debt stock rearrangements or reductions are established on the condition that the sovereign debt defaulter implements structural adjustments in its economy.

${ }^{23}$ The approach developed by Fafchamps (1995) could be used to assess the power of "conditionalities" of reducing disincentives associated with debt overhang. In short, this refers to a state of nature in which foreign debt obligations are so strong that they discourage investments, since a significant part of the product of these investments would be destined for foreign creditors.
} 
sion is temporary. Looking at the theoretical literature within the context of the problem with the principal and agent, with no exception, the potential penalty meets the restriction on incentives - it is incentive compatible - the loss of access to the international credit market is enough for the sovereign debtor to maintain the strategy of servicing his debts.

Jeanne (2000) advocates that there must be reasons that justify the preferences of international creditors and debtors from emerging economies for short-term contracts - supposedly more costly for both parties in case of exchange rate crisis - in detriment to longterm contracts. In addition, this author states that it is important to understand these reasons in order to forecast changes in the international and regulatory framework - in conditions of equilibrium, the financing structure of the aforementioned economies would be affected.

In order to analyze the propositions outlined above, among others, in more detail, Jeanne (2000) presents a model in which the maturity of the external public debt is endogenized, as a result of commitment assumption. This way, the theory allows for the assessment of effects on the welfare of lenders and borrower, triggered by the occasional existence of an international last instance lender. The author recognizes that the main conclusion of the study may be seen as specific to the theory about debt maturity, that is, the short-term loans would act as an optimal guarantee that the importing economy will maintain fiscal discipline - under the risk of non-rollover, the economy would be forced to maintain discipline. The maintenance of discipline, in its turn, is nothing but an indication the debt will be paid off, opening room for the survival of the international credit market, in this case, targeted at emerging economies.

Drazen (2000) summarizes in a few words the contents of the previously discussed class of models. For this author, the threat of 
punishment is what really matters. Furthermore, this author argues that the punishment can never be applied in equilibrium, and that the characteristic of the contract is determined by the threat of punishment. Finally, although the theory of reputational equilibrium enjoys great prestige, part of the literature makes some restrictions on it. This rationale is discussed in the subsequent subsection.

\subsection{Denial of reputational equilibrium.}

This subsection explores some arguments against the reputational equilibrium. The literature that challenges the theory of reputational equilibrium is briefly discussed. Bulow and Rogoff (1989) advocate that loans to small economies should be guaranteed by the development of mechanisms that allow creditors to apply direct sanctions in cases of default. The guarantees considered in the approach of reputational equilibrium alone would not form a collateral that could actually protect the lender.

Through this differentiated perspective, Bulow and Rogoff (1989) construct a theory according to which, it is crucial for the survival of the international credit market that creditors have political rights that allow them to threaten the interests of debtors outside their credit relations. In opposition to the arguments listed in the previous subsection, the exclusion from the credit market would not therefore solve the problem of voluntary default. An alternative collateral, according to these authors, could be the establishment of legal rights that could lead creditors to halt the international trade of the debtor country or to arrest assets of debtors outside their frontiers.

To get to the propositions mentioned above, Bulow and Rogoff (1989) compare the benefits of two strategies - to pay or to repudi- 
ate $\mathrm{e}^{24}$ - in an economy with insurance contracts against consumption losses, whose premiums should be paid in advance- contracts such as cash-in-advance. By admitting that debt defaulters have access to this contract as an insuree and that insurance companies do honor the insurance policies, the authors turn to the no-arbitrage condition to demonstrate that reputational equilibrium would not be sustainable, and also show that there would be states of nature in which default would certainly occur ${ }^{25}$. In Drazen's interpretation (2000), there would be sufficiently good states of nature, in which the debtor would default and at the same time would use the expropriated resources to get a cash-in-advance insurance.

Rosenthal (1991) also questions the sustainability of reputational equilibrium. Contrary to Bulow and Rogoff (1989), in whose theory a debt defaulter loses access to the international credit market as a borrower only, Rosenthal (1991) totally denies access to the credit market, both as borrower and lender. The fact that the simplifying hypotheses are different does not prevent us from obtaining similar conclusions from the two studies: separately, reputational guarantees cannot sustain the international credit market ${ }^{26}$.

Cole and Kehoe (1996) observe that even when the validity of reputational equilibrium is questioned, Bulow and Rogoff (1989) rec-

\footnotetext{
${ }^{24}$ Especially at this point, the theory postulated by Bulow and Rogoff (1989) does not differ from those that defend the sustainability of reputational equilibrium.

${ }^{25}$ Also see Eaton and Fernandez (1995). For these authors, however, the two hypotheses on which Bulow and Rogoff (1989) construct their theory are unrealistic: (i) the access to insurance contracts against consumption losses; and (ii) the commitment of the insurer to always pay the insurance policy, as the reputational contract would be followed only when the sovereign economy was the creditor.

${ }^{26}$ The imposition that intertemporal discount rate should be higher than the rate of return in the credit market is crucial to explain the results obtained by Rosenthal (1991). Within this context, the agent values current consumption more than future consumption and, therefore, has more incentives to default.
} 
Political risk, incentives and international credit market equilibrium

ognize that this concept would not be necessarily buried. More precisely, once countries are involved in a series of interrelationships, reputation could support indebtedness, even under the hypothesis that the cash-in-advance contracts mentioned before exist. For this purpose, the analysis should be expanded, going from the context of partial equilibrium, where the debt is dealt with separately, to the context of general equilibrium, where all relations are considered.

From the conjecture of Bulow and Rogoff (1989), Cole and Kehoe (1996) work on a model where the inadequate behavior of the country in the credit area leads to loss of reputation in other areas. The major conclusion is that in case of repeated relations (with constant benefits in each period), the conjecture outlined above could be valid. On the other hand, in dynamic relations (with benefits dependent on state variables), reputational equilibrium could not be valid once again.

\section{Final considerations.}

This article aimed at analyzing, although partially, the state-ofthe-art in terms of the incentives that move economic agents in their transactions in the international credit market. At first, the issue was analyzed in the perspective of lenders and later in the view of borrowers.

By analyzing the supply, we conclude that the arguments presented in the literature to explain the preference of international investors for economies other than their own, are somewhat associated with the search for a greater return (a view that was formalized by Keynes, by means of interest rate parity conditions) and/or the search for the diversification of the investment portfolio (a view formalized by Markowitz, by means of the mean-variance model). In both situations, however, we could say that capitalists would be in search of consumption smoothing. Identically, the argument that 
best explains the receipt of foreign capital is consumption smoothing. In this sense, the classical notion that a return from the higher capital to cost justifies the external indebtedness of economies is still accepted.

Given the nonexistence (or inefficiency) of coercive law mechanisms, it is essential to identify under which conditions the existence of nontrivial equilibrium is guaranteed in the international credit market. Thus, we examined the literature that defends the validity of reputational equilibrium and also the one in which reputational equilibrium is not sustainable. Roughly, we conclude that the matter is still open to investigation.

As stated in the introduction, our aim was not to cover all the literature on international capital flow or on the topics discussed herein. We understand that possible extension of this study could be made by a literature review on the phenomenon of capital flow in other perspectives, such as that which is offered by the theory of corporative finances and of asset pricing.

Submitted in January 2002. Revised in August 2002.

\section{References}

Aliber, R. Z. 1973. "The Interest Parity Theorem: A Reinterpretation", Journal of Political Economy, 81:1451-9.

Araújo, C. H. V. 2000. "Movimentos de Capitais - O Financiamento Externo à Economia Brasileira: 1991-1998", Tese de Doutoramento, Escola de Pós-Graduação em Economia, da Fundação Getulio Vargas.

Atkenson, A. 1991. "International Lending with Moral Hazard and Risk Repudiation", Econometrica, 59:1069-1090. 
Political risk, incentives and international credit market equilibrium

Bulow, J. \& K. Rogoff 1989. "Sovereign Debt: Is to Forgive to

Forget?", American Economic Review, March, 43-50

Buiter, W. H. 1983. "Implications for the Adjustment Process of International Asset Risk: Exchange Controls, Intervention and Policy Risk, and Sovereign Risk", in R. G. Hawkins, R. M. Levich \& C. G. Wihlborg (Eds.), The Internationalization of Financial Markets and National Economic Policy, Jai Press Inc.

Chowdhry, B. 1991. "What is Different about International Lending?", Review of Financial Studies, 4(1):121-148

Claessens, S., M. Dooley \& A. Warner 1995. "Portfolio Flows: Hot or Cold?", The World Bank Economic Review, 1, January, 153174.

Cole, H. L. \& W. B. English 1995. "Direct Investment: A Doubtful Alternative to International Debt", Federal Reserve Bank of Minneapolis Quarterly Review, 16(1).

Cole, H. L., J. Dow \& W. B. English 1995. "Default, Settlement, and Signaling: Lending Resumption in a Reputational Model of Sovereign Debt", International Economic Review, 36(2)365-385.

Cole, H. L. \& P. J. Kehoe 1996. "Reputation Spillover Across Relationships: Reviving Reputation Models of Debt", National Bureau of Economic Research Working Paper 5486.

Dooley, M. P. \& P. Isard 1980. "Capital Controls, Political Risk and Deviation from Interest-Rate Parity" , Journal of Political Economy, 88, 70-84.

Drazen, A. M. 2000. "Political Economy in Macroeconomics", Princeton University Press.

Eaton, J. \& MI. Gersovitz 1980. "LDC participation in International Financial Markets: Debt and Reserves", Journal of Development Economics, 7(1)3-21. 
Eaton, J. \& M. Gersovitz 1981. "Poor-Country Borrowing in Private Financial Markets and the Repudiation Issue", Princeton Studies in International Finance, 47, July.

Eaton, J. \& M. Gersovitz 1983. "Country Risk: Economic Aspects", Yale University, Economic Growth Center, Center Paper 349.

Eaton, J., M. Gersovitz \& J. Stiglitz 1986. "The Pure Theory of Country Risk", European Economic Review, 30(3)481-513.

Eaton, J. \& R. Fernandez 1995. "Sovereign Debt", National Bureau of Economic Research Working Paper 5131.

Edwards, S. 1984. "LDC Foreign Borrowing and Default Risk: An Empirical Investigation, 1976-1980", American Economic Review, 4:726-734.

Edwards, S. 1986. "The Pricing of Bonds and Banks Loans in International Markets", European Economic Review, 30(3)565589.

English, W. 1996. "Understanding the Costs of Sovereign Default: American State Debts in the 1840's", American Economic Review, 259-275.

Evans, J. L. \& S. H. Archer 1968. "Diversification and the Reduction of Dispersion: An Empirical Analysis", Journal of Finance, December, 761-767.

Fafchamps, M. 1996. "Sovereign Debt, Structural Adjustment, and Conditionality", Journal of Development Economics, 50(2)313335.

Feder, G. \& K. Ross 1982. "Risk Assessments and Risk Premiums in the Eurodollar Market", Journal of Finance, 37:679-691.

Francis, J. C. 1986. "Investments: Analysis and Management", 4th issue, Mcgraw-Hill.

Frankel, J. A. 1979. "The Diversifiability of Exchange Risk", Jour- 
Political risk, incentives and international credit market equilibrium

nal of International Economics.

Frankel, J. A. 1995. "Monetary Regime Choice for a Semi-Open Country", in Sebastian Edwards, editor, Capital Controls, Exchange Rates, and Monetary Policy in the World Economy, Cambridge University Press.

Garcia, M. G. P. \& A. Barcinski 1996. "Capital Flows to Brazil in the Nineties: Macroeconomic Aspects and the Effectiveness of Capital Controls", Text for Discussion 357, Department of Economics, PUC-RJ.

Golub, S. S. 1990. "International Diversification of Social and Private Risk: The U. S. and Japan", Yale Cowles Foundation Discussion Paper 955.

Grauer, R. R. \& N. H. Hakansson 1987. "Gains from International Diversification: 1968-85 Returns on Portfolios of Stocks and Bonds", Journal of Finance, 42(3), July.

Grauer, R. R. \& N. H. Hakansson (1986), "A Half Century of Returns on Levered and Unlevered Portfolios of Stocks, Bonds, and Bills, with and without Small Stocks", Journal of Business, 59(2), Part 1, April, 287-318.

Grossman, H. I. \& J. B. van Huyck 1988. "Sovereign Debt as a Contingent Claim: Excusable Default, Repudiation, and Reputation", American Economic Review, 78(5)1088-1097.

Grossman, H. I. \& T. Han 1997. "Sovereign Debt and Consumption Smoothing", National Bureau of Economic Research Working Paper 5997.

Grubel, H. G. 1968. "Internationally Diversified Portfolios: Welfare Gains and Capital Flows", American Economic Review, December, 1299-1314.

Hermalin, B. E. \& A. K. Rose 1999. "Risks, Lenders and Borrowers in International Capital Markets", National Bureau of Economic 
Research Working Paper 6886.

Huang, C. \& R. H. Litzemberger 1988. "Foundations for Financial Economics", North-Holland.

Isard, P. 1995. "Exchange Rate Economics", Cambridge Surveys of Economic Literature, Cambridge University Press.

Jeanne, O. 2000. "Sovereign Debt Crises and the Global Financial Architecture", unpublished article.

Kletzer, K. M. 1984. "Asymmetries of Information and LDC Borrowing with Sovereign Risk", The Economic Journal, June, 287307.

Levy, H. \& M. Sarnat 1970. "International Diversification of Investment Portfolios", American Economic Review, 60(4)668-675.

Lucas, R. 1990. "Why Doesn't Capital Flow from Rich to Poor Countries?", American Economic Review Papers and Proceedings, 80(2), May.

Merton, R. 1973. "An Intertemporal Capital Asset Pricing Model", Econometrica, 41, September, 867-887.

Obstfeld, M. \& K. Rogoff 1996. "Foundations of International Macroeconomics", MIT Press, Cambridge, Massachusetts.

Rosenthal, R. W. 1991. "On the Incentives Associated with Sovereign Debt", Journal of International Economics, 30 (1/2)167-176.

Simonsen, M. H. 1983. "Dinâmica Macroeconômica", MccGraw-Hill do Brasil, São Paulo.

Solnik, B. H. 1974. "An Equilibrium Model of the International Capital Market", Journal of Economic Theory, 8(4), August, 500-524.

Statman, M. 1990. "How Many Stocks Make a Diversified Portfolio?", in D. H. Miller and S. C. Myers (editors), Frontiers of 
Political risk, incentives and international credit market equilibrium

Finance, Basil Blackwell, 468-480.

van Wincoop, E. 1999. "How Big Are Potential Welfare Gains from International Risksharing?", Journal of International Economics, 47(1), February, 109-135. 